\title{
O currículo e a formação do enfermeiro
}

\author{
Jussara Gue Martini \\ Editor Científico da REBEn e Diretora de Publicações e Comunicação Social da ABEn (2007-20I0)
}

Uma das Questões fundamentais para a mudança da educação superior em nosso país é a busca de resposta sobre Qual o sistema educativo, Qual Universidade, dará conta do desenvolvimento de uma sociedade marcada pela produção intensa de conhecimentos e de informações, aliada a uma profunda crise de civilização.

O Curso de graduação em Enfermagem tem se pautado pela permanente inquietude com relação á formação de seus egressos, preocupação Que tem determinado a busca permanente por metodologias e tecnologias de ensino/ aprendizagem e de cuidado Que possibilitem a formação do/a enfermeiro/a com competências técnicas e políticas para o exercício profissional.

A par de tudo isso, move-nos a compreensão de Que, desde as suas origens, a formaçãa das práticas sociais de Enfermagem, tem por meta um perfil profissional Que cultiva traços de caráter, aliados às competências técnicas, éticas e políticas. No caminho percorrido, desde as primeiras escolas de Enfermagem até o momento, pode-se identificar a preocupação com a defesa dos espaços ocupados pela categoria, determinando a busca constante por um referencial teórico sistematizado e autônomo, remetendo à intenção de legitimar um conhecimento específico da Enfermagem.

Assim, pode-se destacar Que, embora o processo de constituição da Enfermagem profissional no Brasil tenha se assentado no ideário hegemônico americano, o embate cotidiano das relações desse ideário com o movimento de consolidação da profissão no Brasil, fortemente ligado a trajetória da Associação Brasileira de Enfermagem ABEn, aos poucos vai transformando as condições Que lhe servem de base, reconstruindo o modelo pedagógico nightingaleliano, configurando suas ideologias e, organicamente, redesenhando um modelo pedagógico de formação das enfermeiras brasileiras.

A ABEn tem um papel estratégico, como aparelho de divulgação do pensamento hegemônico no ensino e prática da Enfermagem, exercendo uma forte influência na produção acadêmica desse saber e na construção dos currículos das escolas.

No desenvolvimento do ensino de Enfermagem no Brasil, é importante destacar que, em período mais recente, as mudanças foram fortemente influenciadas pelo movimento sanitarista. Assim, o contexto Que antecedeu a substituição do currículo de Enfermagem de 1972 por uma nova proposta curricular, concretizada na década de noventa, foi circundado por uma série de mudanças sócio-políticas e culturais na sociedade brasileira, Que formaram o terreno fértil de geração de uma nova compreensão de produção dos serviços de saúde.

Desse modo, influenciados por movimentos Que provocaram mudanças no ensino e, por outro lado, pelo contexto de mundialização do capital, foram construídas as diretrizes Curriculares Nacionais do Curso de Enfermagem/200 I , atendendo às determinações da lei de diretrizes e Bases da Educação Nacional, lei 9394/96, na perspectiva de maior flexibilidade na estruturação curricular e na formação de um profissional generalista, humanista, crítico e reflexivo.

Entende-se o currículo como um campo de conflitos de poder na prática interdisciplinar, frutos do processo de inserção histórica de cada profissão na divisão social e técnica do trabalho e da constituição dos saberes próprios como estratégias de poder. Um campo de reprodução e de resistência, no Qual o entendimento sobre "o Que ensinar" ou "Quanto ensinar" vincula-se às relações de poder e à luta por um certo tipo de sociedade. Expresso como mandato social concedido, tanto pela sociedade como pelo Estado, sobre um campo específico à determinada profissão, envolvendo o conteúdo da cultura profissional, composta por um conjunto de valores culturais, de identidades sociais e de preferências teóricas e técnicas, construídas em um processo histórico de institucionalização de organizações corporativas.

Este processo histórico de constituição dos princípios de formação dos Enfermeiros nos autoriza a resistir a uma determinação externa sobre o tempo necessário para dar-se conta de um itinerário de ensinoaprendizagem que nos habilite ao exercício do cuidado, em toda sua complexidade. 